This article was downloaded by: [Lancaster University Library]

On: 22 April 2013, At: 08: 32

Publisher: Routledge

Informa Ltd Registered in England and Wales Registered Number: 1072954 Registered office:

Mortimer House, 37-41 Mortimer Street, London W1T 3J H, UK

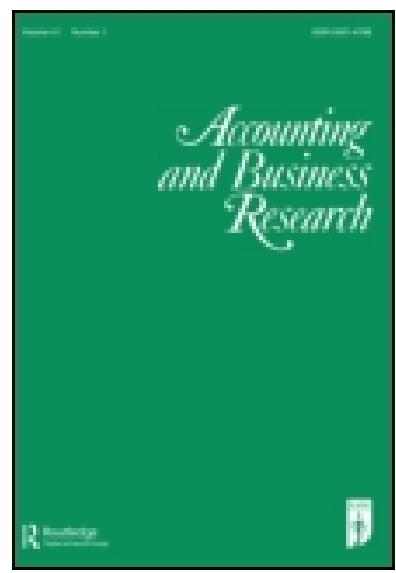

\title{
Accounting and Business Research
}

Publication details, including instructions for authors and subscription

information:

http:// www. tandfonline.com/loi/ rabr20

\section{Cross-border information transfers: Evidence from profit warnings issued by European firms}

\author{
Paulo Alves ${ }^{a b}$, Peter F. Pope ${ }^{c} \&$ Steven Young ${ }^{d}$ \\ a Universidade Católica Portuguesa, Porto \\ ${ }^{b}$ International Centre for Research in Accounting, Lancaster University \\ ${ }^{c}$ Lancaster University Management School \\ d Lancaster University Management School, Lancaster University, Lancaster, \\ LA1 4YX Phone: + 44 (0) 1524594242 E-mail: \\ Version of record first published: $04 \mathrm{~J}$ an 2011.
}

To cite this article: Paulo Alves, Peter F. Pope \& Steven Young (2009): Cross-border information transfers: Evidence from profit warnings issued by European firms, Accounting and Business Research, 39:5, 449-472

To link to this article: http:// dx. doi.org/ 10.1080/00014788.2009.9663378

PLEASE SCROLL DOWN FOR ARTICLE

Full terms and conditions of use: http://www.tandfonline.com/page/terms-and-conditions

This article may be used for research, teaching, and private study purposes. Any substantial or systematic reproduction, redistribution, reselling, loan, sub-licensing, systematic supply, or distribution in any form to anyone is expressly forbidden.

The publisher does not give any warranty express or implied or make any representation that the contents will be complete or accurate or up to date. The accuracy of any instructions, formulae, and drug doses should be independently verified with primary sources. The publisher shall not be liable for any loss, actions, claims, proceedings, demand, or costs or damages whatsoever or howsoever caused arising directly or indirectly in connection with or arising out of the use of this material. 


\title{
Cross-border information transfers: evidence from profit warnings issued by European firms
}

\author{
Paulo Alves, Peter F. Pope and Steven Young*
}

\begin{abstract}
This paper reports evidence on cross-border accounting information transfers associated with profit warning announcements. Using a sample of firms from 29 European countries, we find that negative earnings surprises disclosed by firms in one country affect investors' perceptions of comparable non-announcing firms in other countries. The form and magnitude of cross-border effects is consistent with domestic transfers. Tests explaining variation in cross-border information transfers provide some (albeit rather limited) evidence that effects vary according to a range of firm-, industryand country-level characteristics.

Keywords: information transfers; profit warnings; stock market reaction; cross-border effects
\end{abstract}

\section{Introduction}

Prior research provides evidence of within-country information transfers in response to earningsrelated news (Firth, 1976; Foster, 1981; Clinch and Sinclair, 1987; Han and Wild, 1990; Freeman and Tse, 1992; Baginski, 1987; Han et al., 1989; Pyo and Lustgarten, 1990; Tse and Tucker, 2006). In contrast, the extent to which investors and analysts extrapolate earnings information across national boundaries has been largely overlooked in the literature despite the relentless globalisation of capital and product markets. This paper reports evidence on the incidence and magnitude of crossborder accounting information transfers within Europe.

The essence of our study is perhaps best illustrated by the following example. On 23 June 2003 Dutch brewing giant Heineken

\footnotetext{
* Paulo Alves is at Universidade Católica Portuguesa (Porto) and the International Centre for Research in Accounting at Lancaster University; Peter Pope and Steven Young are at Lancaster University Management School. The authors are grateful for helpful comments and suggestions from the editor, two anonymous reviewers, Martin Walker, and seminar participants at the Financial Reporting and Business Communication Conference (Cardiff, 2007), the Portugese Finance Network Conference (Coimbra, 2008). They are also grateful to OMAM Ltd for providing the Morgan Stanley MSCI data. Financial support was provided by the Centre for Business Performance at the ICAEW, the International Centre for Research in Accounting, the European Commission (INTACCT research training network, project no. 35850), and Fundação para a Ciência e Tecnologia (Portugal, project reference SFRH/BPD/ 34034/2006)

Correspondence should be addressed to: Steven Young, Lancaster University Management School, Lancaster University, Lancaster LA1 4YX. Tel: ++ 44 (0) 1524594242. E-mail: s.young@lancaster.ac.uk.

This paper was accepted for publication in May 2009
}

announced that half-yearly earnings growth would remain flat. Not only did the news prompt a $12 \%$ drop in Heineken's share price; it also caused shares in Interbrew (Belgium) and Carlsberg (Denmark) to fall by $4 \%$ and $5 \%$, respectively (Financial Times, 24 June 2003). Clearly, investors and analysts considered news of Heineken's performance useful in updating expectations about other firms in the European brewing sector. With more firms transacting a larger fraction of their business across national boundaries, the relevance of financial results released by firms in one country for their foreign peers is likely to be on the rise.

We test for evidence of cross-border information transfers using profit warnings (i.e. voluntary trading updates that signal a material deterioration in profitability and earnings relative to market expectations). Our analysis utilises 4,283 firms from 29 European countries over the period January 1997 through December 2007. Restricting the analysis to European-listed firms represents a compromise between scope and feasibility. It also yields a sufficiently broad cross-section of economic, political and regulatory environments to facilitate a rich analysis of crossborder effects, while simultaneously ensuring that earnings information remains relevant for nonannouncing firms (by confining the analysis to a single economic zone).

Tests provide evidence that negative earnings surprises affect investors' perceptions of comparable foreign non-announcing firms. The average market-adjusted price reaction for foreign nonannouncers is statistically negative, suggesting that 
contagion effects dominate in the cross-section. Non-announcing firms are also associated with abnormally high trading volume and downward revision in analysts' earnings forecasts during the announcement window. Comparing the magnitudes of within- and cross-country transfers reveals that the average market reaction for foreign nonannouncers is statistically similar to that experienced by domestic non-announcers. Cross-sectional tests provide evidence that cross-border transfers vary according to firm-, industry- and country-level characteristics. However, results are far from clear-cut: findings vary across alternative market response metrics; associations are not symmetric with respect to contagion and competitive effects; and the explanatory power of the models is typically low.

Evidence concerning cross-border information transfers contributes to prior research in several ways. First, Firth (1996a) is the only published study to our knowledge that directly tests whether investors and analysts extrapolate earnings information across national boundaries from announcing to non-announcing firms. While Firth's (1996a) results provide evidence consistent with crossborder information transfers associated with corporate earnings announcements, his analysis is restricted to two countries with strong economic and institutional links (the US and UK). Despite these commonalities, however, Firth (1996a) documents asymmetry in the strength of cross-border transfers, with larger effects observed for US announcers. Our analysis extends Firth (1996a) by documenting the presence of earnings-related information transfers in a more extensive set of countries characterised by a broader range of political, legal, and financial reporting arrangements. Second, evidence on cross-border earnings information transfers speaks to the ongoing debate surrounding the impact of international accounting diversity on the usefulness of financial statement data. The demand for improved harmonisation of international financial reporting practices to facilitate better comparative analysis is one of the main driving forces behind the adoption of International Financial Reporting Standards (IFRS). To the extent that our sample period is characterised by considerable cross-country accounting diversity, evidence of cross-border transfers similar in form and magnitude to those observed between firms within a country suggests that GAAP differences do not necessarily prevent investors from conducting international comparative analyses. Third, profit warnings may be viewed as a special category of management forecasts. Although the literature on management forecasts is extensive (see Hirst et al., 2008), few papers have examined management forecasts in an international context. ${ }^{1}$ Our paper contributes to this line of research by providing evidence on the incidence and informativeness of profit warnings in a broad set of European countries.

The remainder of the paper is organised as follows. Section 2 locates our analysis within the extant literature. Section 3 describes the research design and introduces the sample and data used to test for evidence of cross-border earnings-related information transfers. Section 4 presents univariate evidence regarding the incidence and magnitude of cross-border transfers. Section 5 investigates crosssectional variation in the magnitude of cross-border information transfers. Section 6 summarises a series of sensitivity tests designed to assess the robustness of our results. Section 7 concludes.

\section{Background, motivation and research question}

Information transfers occur when an announcement made by one firm contemporaneously provides information about the performance and value of one or more non-announcing firms (Schipper, 1990: 97). In the accounting literature, the majority of information transfer research has focused on earnings-related announcements and events. ${ }^{2}$ Using a small sample of UK firms, Firth (1976) tested whether earnings announcements impact stock prices of reporting firms' non-announcing industry peers. Firth's (1976) results support the view that announcing firms' earnings contain information relevant for valuing non-announcing firms. Subsequent research by Foster (1981), Clinch and Sinclair (1987), Han and Wild (1990), Freeman and Tse (1992), and Joh and Lee (1992) explored intraindustry information transfers in relation to US firms' earnings announcements, while other studies have examined information transfers associated with management earnings forecasts (Baginski, 1987; Han et al., 1989; Pyo and Lustgarten, 1990), profit warnings (Tse and Tucker, 2006),

\footnotetext{
${ }^{1}$ Notable exceptions include Baginski et al. (2002) who compare disclosure of management earnings forecasts in US and Canadian markets, and Frost (2000) who provides comparative descriptive evidence on disclosures of forwardlooking information in the US and several European countries for firms in the manufacturing sector.

${ }^{2}$ Finance researchers have examined the information transfer phenomenon in a variety of corporate contexts including bankruptcy filings (Lang and Stulz, 1992), bank failures (Aharony and Swary, 1983), merger proposals (Eckbo, 1983), dividend initiations (Firth, 1996b), stock repurchases (Hertzel, 1991), management buyouts (Slovin et al., 1991), corporate accidents (Bowen et al., 1983), and public securities offerings (Szewczyck, 1992).
} 
and earnings restatements (Xu et al., 2006; Gleason et al., 2008). The conclusion emerging from this body of work is that earnings-related news events are associated with statistically significant transfers of information from announcing to non-announcing firms, although the magnitude of the market reaction for non-announcers tends to be considerably smaller than that observed for announcers.

Earnings surprises containing state-of-the-sector information may impact announcing firms' peers in one of two ways. Surprises that signal changes in the size of the overall sector pie are expected to affect announcing and non-announcing firms similarly, with favourable (unfavourable) news leading to positive (negative) shocks for both groups. These same-sign information transfers are often labelled contagion effects. Conversely, holding demand within a sector constant, an earnings innovation reported by one firm may signal a shift in its competitive position with respect to other firms in the same sector, with a negative (positive) surprise implying good (bad) news for its non-announcing peers. Opposite-sign information transfers that reflect a redistribution of a constant industry pie are often labelled competitive effects. Although examples of both types of transfer have been documented in the literature (Lang and Stulz, 1992; Firth, 1996a), evidence for earnings-related information transfers suggests that contagion effects dominate in the cross-section (Firth, 1976; Foster, 1981; Clinch and Sinclair, 1987; Han and Wild, 1990; Tse and Tucker, 2006).

While prior research reveals interdependencies among firms' share prices based on key accounting disclosures and major corporate events, results are almost exclusively confined to within-country effects. Notable exceptions include studies examining the Latin American debt crisis (Madura et al., 1991; Diaz and McLeay, 1996) and the effects of the Enron scandal (Cahan et al., 2005). To the best of our knowledge, Firth (1996a) is the only published study that tests for evidence of cross-border information transfers in the context of earnings disclosures. Firth (1996a) investigates information transfers between US and UK firms associated with corporate earnings announcements. Findings reveal evidence of statistically significant earnings information transfers, although the cross-border effects are reliably smaller than corresponding within-country transfers. US announcers are associated with larger cross-border transfers than UK announcers, reflecting the international importance of the US corporate sector coupled with earlier reporting by US firms relative to their UK counterparts with comparable fiscal year-ends.
Evidence presented by Firth (1996a) reveals that institutional, regulatory, and financial reporting differences between the US and UK are not sufficient to impede cross-border extrapolation of corporate earnings surprises. As Firth (1996a) acknowledges, however, cross-border earnings information transfers are more likely to exist between this pair of countries than many other groups of nations because of the strong linkages between US and UK financial markets and corporate activities. An unresolved question is whether analysts and investors extrapolate earnings information across national boundaries in the face of substantial institutional, legal, political, cultural and financial reporting differences.

Building on Firth (1996a), we employ a large sample of firms from a broad set of European countries to test whether firm-specific earningsrelated news disclosures convey information to stock market investors about the performance and value of comparable foreign firms. While the existence of cross-border earnings-related information transfers is intuitively appealing, several factors militate against observing such effects in practice. First, such effects rely on the assumption that firmspecific accounting releases contain common information useful in updating expectations about nonannouncing firms. Whereas this assumption may be axiomatic at the country level for well-developed financial reporting systems such as the US or UK (Schipper, 1990), it is less obviously so in a crosscountry setting where the quality of financial reporting varies and where some accounting systems are designed for purposes other than reflecting underlying economic reality (e.g. tax-based systems). Second, Ball (2006) conjectures that despite extensive international integration of capital and product markets, most economic and political activity remains intranational. To the extent that firms' activities are shaped largely by domestic considerations rather than global factors, the scope for cross-border information transfers for the average firm may be limited. Third, even when earningsrelated information transfers do occur, the empirical challenge of detecting such activity is far from straightforward (Schipper, 1990). The problem of low power is likely to be especially acute in a crosscountry setting given heterogeneity in economic, political, cultural and regulatory factors (Firth, 1996a).

We test for evidence of cross-border earningsrelated information transfers in Europe using a sample of profit warning announcements. Profit warnings offer several research design advantages with respect to our analysis. First, since earnings 
information transfers are likely to be small and difficult to detect (Schipper, 1990; Firth, 1996a), high power tests are required to reject the null hypothesis of no information spillover. Prior research indicates that the scope for earnings transfers is increasing in the magnitude of the earnings surprise (e.g. Firth, 1996a). Profit warnings, which are associated with dramatic valuation effects for announcing firms (Kasznik and Lev, 1995; and Clarke, 2001; Helbok and Walker, 2003; Collett, 2004), therefore provide a potentially powerful context in which to test for cross-border transfer effects. Second, whereas periodic earnings announcements require estimation of the surprise component, profit warnings represent earnings surprises by construction. Consequently, our tests are not constrained by the availability of analyst forecast data, which can be patchy in some European countries. Third, because profit warnings do not follow a systematic disclosure pattern during the fiscal year, they help overcome the problem of crossevent contamination common to other accounting disclosures such as annual or interim earnings announcements that cluster in calendar time.

\section{Sample, data and methods}

\subsection{Sample selection}

Our analysis examines whether profit warnings issued by firms resident in one country convey information to stock market investors about the performance and value of similar non-announcing firms in other countries. For each profit warning announcement in country $k$ we identify all comparable foreign non-announcing firms at the event date (including firms that warned at other times during the sample period). Warnings announced between January 1997 and December 2007 by European publicly traded firms form the basis of our tests. ${ }^{3}$ Profit warning data are obtained from JCF Quant/ Factset (now ExtelConnect). The sample period begins in 1997 because coverage of profit warning announcements on JCF is limited prior to this date.

The sample selection procedure involves first identifying all European-listed firms included in the JCF proprietary international industry portfolios with market capitalisation data for at least one fiscal

\footnotetext{
${ }^{3}$ Rules governing when and how European firms issue warnings vary across countries. For example, Berglund and Westerholm (2007) note that Finnish Supervisory Authority rules require firms to warn when performance or financial position is worse or better than expected. Similar rules exist in the UK (e.g. PSI Rule 1 and Rule 2). In contrast, firms in some countries never issue warnings, suggesting the absence of any regulatory requirement for firms to update investors in situations where expectations and actual performance are materially misaligned.
}

year-end during the sample period. ${ }^{4}$ The resulting sample comprises 11,835 firms from 30 countries. The total number of profit warnings available on JCF for these firms during the sample window is $3,635 .^{5}$ Financial statement and market data required for our tests are drawn from Datastream. While only 6,135 firms (52\%) from the initial JCF sample are located on Datastream, the corresponding reduction in the profit warning sample to 2,482 observations is less than $32 \%$. This is consistent with our matching procedure excluding a disproportionately high number of small firms that are less likely to warn. This preliminary sample is then refined as follows. First, observations with missing announcement-period price data required for our market reaction tests are excluded. Second, profit warnings for which a comparable foreign nonannouncer cannot be identified at the event date are excluded because our tests require at least one foreign non-announcing peer firm. Third, profit warnings released within four days of a warning issued by another firm in the same sector are excluded to avoid possible contamination caused by overlapping event windows. Fourth, warnings with non-negative announcement-period abnormal returns for the issuing firm are removed because such observations further complicate our analysis. ${ }^{6}$ Fifth, firms classified by JCF as investment trusts are excluded due to the unique nature of their regulatory and financial reporting environment. We also drop firms that JCF does not allocate to a specific industry sector. Finally, countries and industry-year combinations with fewer than three firms are excluded because it is hard to draw meaningful conclusions about cross-border information transfers from such sparse data. The final sample consists of 4,283 firms drawn from 29 countries, and 1,357 profit warnings issued by firms from 20 countries. Most firms $(3,479)$ did not warn during our sample period. Of the 804 announcing firms, 497 (62\%) issued a single warning, 165 firms

\footnotetext{
${ }^{4}$ Firms are considered European-listed when their JCF primary stock listing code refers to a recognised European exchange.

5 An earlier version of the paper focused on the last warning issued by a firm in a given fiscal year because JCF only retained the final announcement for firms issuing multiple warnings during a fiscal year. Following a database upgrade in late 2007 JCF now reports all profit warning announcements. We therefore recollected our sample of warnings to avoid potential sampling biases.

${ }^{6}$ Non-negative price responses for the 365 announcements in our initial sample are most likely caused by 'positive' warnings (see footnote 3 for evidence that regulations in some European countries require firms to warn when actual performance exceeds expectations). Sensitivity tests reveal that including these cases does not impact materially on our findings and conclusions.
} 


\section{Table 1}

Sample selection and composition

Panel A: Sample selection process

\begin{tabular}{|c|c|c|}
\hline & Firms & Profit warnings \\
\hline $\begin{array}{l}\text { JCF Factset European population with market capitalisation between } \\
1997 \text { and } 2007\end{array}$ & 11,835 & 3,635 \\
\hline $\begin{array}{l}\text { Datastream European population with market capitalization between } \\
1997 \text { and } 2007\end{array}$ & 11,352 & N/A \\
\hline Intersection of Datastream and JCF Factset samples & 6,135 & 2,482 \\
\hline \multicolumn{3}{|l|}{ Less: } \\
\hline Firms with missing price data at announcement date & $(659)$ & $(253)$ \\
\hline Investment trusts and unclassified firms & $(795)$ & $(64)$ \\
\hline No comparable foreign non-announcers at announcement date & $(179)$ & $(230)$ \\
\hline Multiple profit warnings within 4-day window & $(27)$ & $(203)$ \\
\hline Profit warnings with non-negative announcement returns & $(182)$ & $(365)$ \\
\hline Countries and industry-year combinations with $<3$ firms & $(10)$ & $(10)$ \\
\hline Final sample & 4,283 & 1,357 \\
\hline \multicolumn{3}{|l|}{ Frequency of profit warnings: } \\
\hline No profit warning & 3,479 & 0 \\
\hline One profit warning & 497 & 497 \\
\hline Two profit warnings & 165 & 330 \\
\hline Three or more profit warnings & 142 & 530 \\
\hline Total & 4,283 & 1,357 \\
\hline
\end{tabular}

\section{Panel B: Final sample by country}

\begin{tabular}{|c|c|c|}
\hline Country & Firms & Profit warnings \\
\hline Austria & 91 & 15 \\
\hline Belgium & 133 & 39 \\
\hline Croatia & 17 & 0 \\
\hline Cyprus & 8 & 0 \\
\hline Czech Republic & 38 & 0 \\
\hline Denmark & 113 & 16 \\
\hline Estonia & 13 & 0 \\
\hline Finland & 89 & 46 \\
\hline France & 509 & 181 \\
\hline Germany & 380 & 86 \\
\hline Greece & 123 & 1 \\
\hline Hungary & 3 & 0 \\
\hline Iceland & 20 & 1 \\
\hline Ireland & 69 & 25 \\
\hline Italy & 223 & 6 \\
\hline Latvia & 14 & 0 \\
\hline Luxembourg & 25 & 5 \\
\hline Netherlands & 180 & 81 \\
\hline Norway & 131 & 25 \\
\hline Poland & 71 & 4 \\
\hline Portugal & 68 & 1 \\
\hline Russia & 143 & 3 \\
\hline Slovakia & 4 & 0 \\
\hline Slovenia & 24 & 0 \\
\hline Spain & 132 & 4 \\
\hline Sweden & 172 & 15 \\
\hline Switzerland & 190 & 47 \\
\hline Turkey & 72 & 0 \\
\hline United Kingdom & 1,228 & 756 \\
\hline Total & 4,283 & 1,357 \\
\hline
\end{tabular}




\begin{tabular}{|lr|}
\hline Table 1 & Profit warnings \\
Sample selection and composition (continued) & 30 \\
\hline Panel C: Final sample of profit warnings by calendar year & 45 \\
\hline 1997 & 18 \\
1998 & 33 \\
1999 & 249 \\
2000 & 202 \\
2001 & 164 \\
2002 & 109 \\
2003 & 156 \\
2004 & 172 \\
2005 & 1,357 \\
2006 & 179 \\
2007 & \\
Total & \\
\hline Note: The sample is based on all announcements classified as profit warnings by JCF Quant/Factset. Firms \\
are considered European-listed when their JCF primary stock listing code refers to a recognised European \\
exchange. JCF and Datastream data are matched using various combinations of the following company- \\
specific identifiers: firm name and parts thereof, SEDOL, ISIN and CUSIP. Comparable foreign non- \\
announcers are defined as firms in the same JCF international industry portfolio as the announcer with a \\
different primary stock listing code. & \\
\hline
\end{tabular}

(20\%) warned twice, and 142 firms (18\%) issued three or more warnings. Sample firms are drawn from 112 out of 130 JFC international industry portfolios. Information technology services account for the largest fraction of warnings (firms) in the final sample at $4 \%(3 \%)$. Panel A of Table 1 summarises the sample selection process.

Panel B of Table 1 reports the frequency of firms and warnings by country. The sample is dominated by firms from the major European exchanges, with $29 \%$ of firms $(1,228)$ listed in the UK, $12 \%(509)$ listed in France, and 9\% (380) listed in Germany. A similar pattern is evident for profit warnings. Untabulated statistics indicate that the proportion of sample firms issuing at least one warning is highest for the UK (62\%), Finland (52\%) and the Netherlands (45\%). Conversely, sample firms in Croatia, Cyprus, Czech Republic, Estonia, Hungary, Latvia, Slovakia, Slovenia, and Turkey do not issue warnings. Panel C of Table 1 reports the distribution of profit warnings by calendar year. The pattern of warnings tracks the business cycle (Clarke, 2001): the peak in warnings coincides with the stock market slow-down in 2001 and 2002, whereas periods of strong economic growth such as 1997-2000 and 2004-2006 are characterised by fewer warnings.

\subsection{Measuring information transfers}

Prior research uses a variety of metrics to measure accounting-related information transfers including announcement-period abnormal stock returns (Han and Wild, 1990; Firth, 1996a; Thomas and Zhang, 2006), announcement-period abnormal trading volume (Weigand, 1996), and analysts' earnings forecast revisions (Pownall and Waymire, 1989; Firth, 1996a; Ramnath, 2002). In the absence of compelling theoretical reasons for favouring one particular approach over another and because each metric is expected to measure transfer effects with error, we report results for all three constructs.

We use market-adjusted returns to measure abnormal stock price movements around the announcement of a profit warning. Daily abnormal returns $(A R)$ for firm $i$ from country $k$ on day $t$ are computed as:

$$
A R_{i k t}=R_{i k t}-R M_{k t},
$$

where $R$ is the Datastream return for firm $i$ on day $t$ and $R M$ is the corresponding value-weighted market return in country $k$ as given by:

$$
R M_{j t}=\sum_{j=1}^{J}\left(R_{j t} \times \frac{M V_{j t}}{\sum_{j=1}^{J} M V_{j t}}\right),
$$

where $M V$ is the market value of firm $j$ on day $t$ and $J$ is the population of stock exchange-listed firms (including firm $i$ ) in country $k$ with returns available from Datastream on day $t$. Since profit warnings may lead to the transfer of negative or positive news to non-announcing firms conditional on the competitive nature of the sector (Schipper, 1990), tests 
are conducted using both signed and absolute abnormal return measures.

Our second information transfer measure is abnormal trading volume $(A V)$ during the period surrounding the profit warning announcement. If profit warnings contain information relevant for valuing announcing firms' peers then we should observe abnormally high levels of trading activity for nonannouncers when a warning is issued. Following Bailey et al. (2003, 2006), announcement-period abnormal trading volume is computed as:

$$
A V_{i t}=\frac{V O L_{i t}}{\sum_{s=t-150}^{t-25} V O L_{i s} / N},
$$

where $V O L$ is the trading volume for firm $i$ on day $t$ and $N$ is the number of trading days from $t-150$ to $t-25$. Unlike directional market-based measures such as price, trading volume provides an absolute measure of the market response to an announcement and as such is capable of capturing both positive and negative information transfers.

If profit warnings contain new insights concerning the expected performance of non-announcing firms then one might expect peer firms' analysts to respond by updating their earnings forecasts to reflect such changes. Accordingly, our third measure of information transfers focuses on revisions in analysts' earnings forecasts. Analysts' forecast revisions $(F R)$ in response to profit warning $p$ announced on day $t$ are computed as the change in the IBES mean consensus annual one-period-ahead earnings per share (EPS) forecast:

$$
F R_{i p}=\frac{E P S_{i t+n}-E P S_{i t-k}}{P_{i m-1}},
$$

where $E P S$ is the IBES mean consensus annual oneperiod-ahead EPS forecast for firm $i, E P S_{t-k}$ is the last consensus EPS forecast available prior to profit warning announcement date $t(k=$ days -180 to $-2), E P S_{t+n}$ is the first consensus EPS forecast available after the profit warning announcement ( $n$ $=$ days -1 to 10), and $P_{m-1}$ is the last available IBES stock price for the month preceding announcement date $t$. Where no consensus forecast is recorded on IBES between days -2 and -180 , the value of $F R$ is set to missing to reduce the impact of stale forecasts. We constrain $n$ at 10 days to limit the opportunity for subsequent events (in particular additional warnings) to contaminate the forecast revision metric. Using a short revision window yields a relatively conservative forecast update metric. $F R$ is set equal to zero when no new IBES consensus EPS value is published during days -1 to 10 to reflect the absence of a forecast revision.

\subsection{Identifying comparable non-announcing firms}

A key research design issue in the earnings information transfer literature is the procedure for identifying comparable non-announcing firms. Consistent with prior research on domestic information transfers (Firth, 1976; Foster, 1981; Pownall and Waymire, 1989; Han and Wild, 1990), our main tests rely on industry classification to identify peer firms. Industry groupings are defined according to the JCF sector classification. The advantages of this approach include simplicity, transparency, and minimal additional data requirements imposed on the sample. Nevertheless, the approach represents a crude and potentially noisy grouping method given the difficulty of allocating firms to industries (particularly for those operating in multiple sectors). Accordingly, the industry-based method is likely to yield relatively low power tests of the information transfer hypothesis. To address this concern, we report supplementary tests in Section 6.2 using two alternative approaches to identifying non-announcing peer firms.

\section{Preliminary results}

\subsection{Announcer effects}

Using profit warnings as the basis for exploring the cross-border information transfer phenomenon is predicated on the assumption that warnings represent significant news events for announcing firms (which in turn lead to spill-over effects for nonannouncing peer firms). Prior research documenting how markets react to profit warnings is confined to the US and UK. Accordingly, Table 2 reports abnormal returns, abnormal trading volume, and analysts' earnings forecast revisions for our sample of European warnings. Since trading volume and analyst forecast data are missing for a substantial fraction of observations, sample sizes are smaller when these metrics are employed.

Pooled sample results reported in Panel A indicate a significant negative market reaction for announcing firms: the average (median) announcement-day abnormal return is $-10.9 \%(-6.4 \%)$, while the equivalent three-day cumulative abnormal return (CAR) centred on the announcement date is $-13.4 \%$ $(-8.7 \%) .^{7}$ In addition, trading volume for the average (median) announcing firm is 7.7 (4.1) times higher than normal on the announcement day ( $p$-value $<0.01$, two-tailed test). Finally, the

\footnotetext{
${ }^{7}$ Similar (though slightly less pronounced) effects are evident if the 365 warnings associated with non-negative announcement-period abnormal returns are retained in the sample. For this combined sample of 1,722 warnings, the median announcement-day abnormal return is $-3.9 \%$ while the median 3-day CAR is $-6.4 \%$
} 


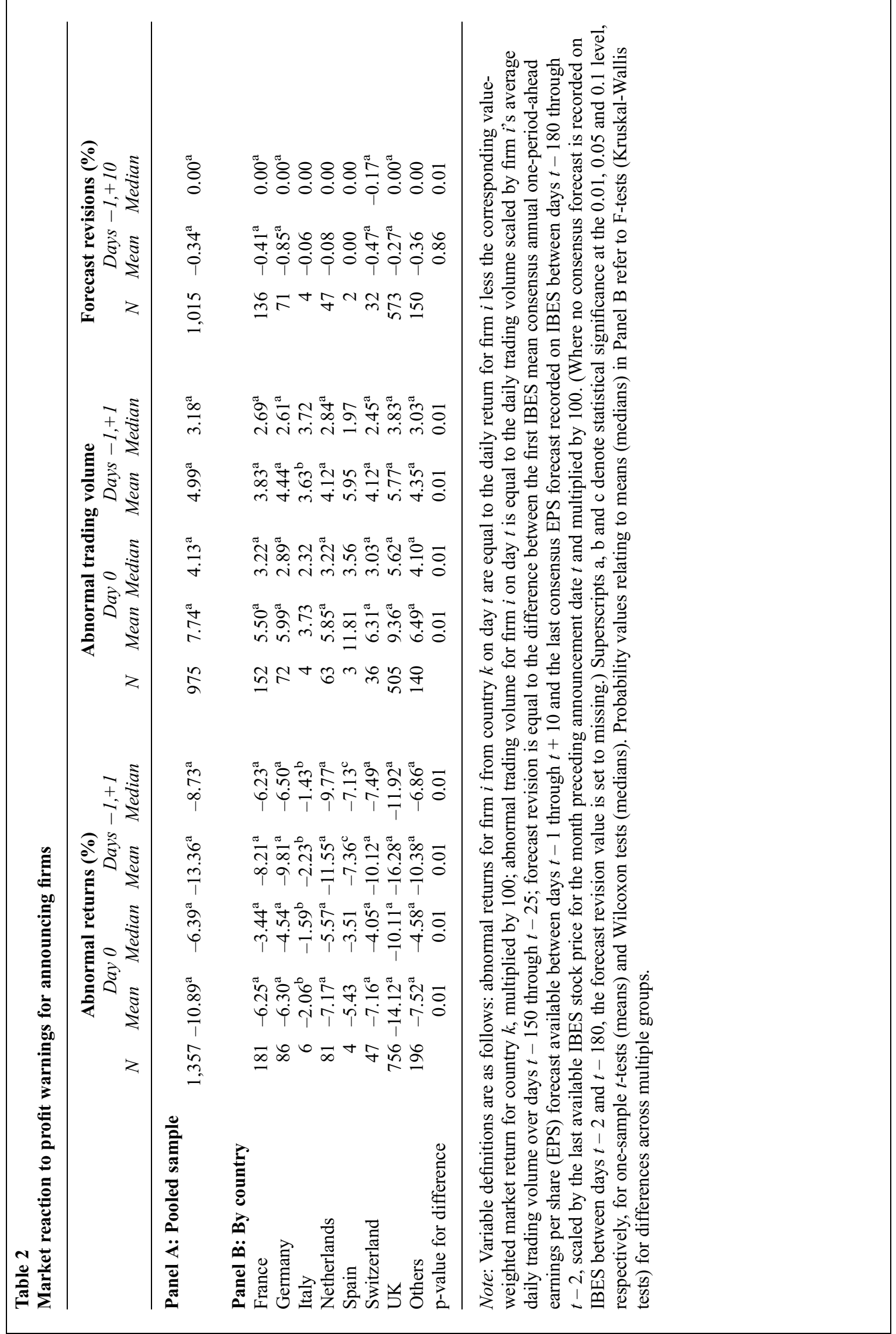


consensus EPS forecast for the average announcing firm falls by $0.3 \%$ of price during the 12 -day window ending 10 days after the profit warning announce-ment ( $\mathrm{p}$-value $<0.01$, two-tailed test). Collectively, these results confirm that European profit warnings contain substantial information about the performance and value of announcing firms.

Panel B of Table 2 presents evidence on the market response to profit warning announcements by country. A consistent pattern of negative announcement-period abnormal returns and abnormally high trading volume is evident for announcing firms in most countries. Exceptions include Spain for announcement-day abnormal returns and abnormal trading volume, and Italy for announcement-day abnormal trading volume. However, all statistical tests and associated inferences for these two countries should be interpreted with caution due to sparse data. Abnormal stock price declines and trading activity are particularly apparent for UK announcers, where the mean announcement-day abnormal return (three-day CAR) is $-14.1 \%$ $(-16.3 \%){ }^{8}$ In contrast to the price and trading volume metrics, downward forecast revisions in response to profit warning announcements are less apparent in many countries with only France, Germany, Switzerland and the UK displaying statistically negative mean (median) revisions. Comparison of mean and median values, however, reveals larger negative revisions in all countries bar Spain. Accordingly, while analysts tend not to adjust downwards their earnings forecasts for the median profit warning announcer in many countries, a small set of disproportionately negative reactions are observed in most countries examined. Finally, cross-country tests reported in the final row of Panel B reveal that announcer effects may not be equivalent across all countries in our sample, suggesting the need to control for announcing firms' country of listing when assessing the incidence and magnitude of cross-border information transfers.

\subsection{Initial evidence on cross-border information transfers}

Table 3 reports evidence on cross-border information transfers in response to profit warnings. Results for comparable domestic transfers (i.e. where nonannouncing firm $j$ is listed in the same country as announcing firm $i$ ) are also presented in Table 3 for comparison. ${ }^{9}$

\footnotetext{
${ }^{8}$ Results for the UK are consistent with those documented by Clarke (2001) for the period 1994-2000 and Collett (2004) for the period 1995-2001. Announcement day returns are less negative than those reported by Helbok and Walker (2003) for the period 1992-1998.
}

Abnormal returns presented in columns 3-4 reveal statistically significant stock price reactions for comparable foreign non-announcing firms in response to profit warning announcements. The average (median) non-announcing peer firm experiences a price fall of $-0.14 \%(-0.12 \%)$ on the day a warning is issued, and a CAR of $-1.29 \%(-0.29 \%)$ over the three-day window centred on the announcement date. Warnings therefore appear to represent bad news for the typical non-announcing firm, consistent with the contagion effects documented by extant research (e.g. Tse and Tucker, 2006). However, the directional effect of warnings on the value of foreign non-announcing peer firms is much less uniform than for announcers: a substantial fraction of non-announcers (46\%) experience non-negative announcement-day abnormal returns. Cross-border information transfers associated with profit warnings do not therefore appear limited to simple contagion effects. Instead, the impact of warnings appears to be a more complex phenomenon associated with gains for some non-announcers (e.g. through actual or expected increases in market share) and losses for others. As documented in previous studies of domestic information transfers, average spill-over pricing effects tend to be small in economic terms (despite their statistical significance). These small magnitudes, coupled with measurement error in abnormal returns, could also account for observed heterogeneity in our pricing results.

Insofar as profit warnings are associated with contagion effects for some non-announcers and competitive effects for others that are roughly symmetric in magnitude, analysis of average signed returns could mask separately non-trivial negative and positive price reactions. Accordingly, columns 6-7 in Table 3 present findings for absolute abnormal returns. ${ }^{10}$ Results reveal relatively large

\footnotetext{
${ }^{9}$ The domestic sample is smaller than the cross-border sample for two related reasons. First, there are fewer warnings with sufficient non-announcers because the domestic pool of industry peers is smaller than the international pool. Second and for similar reasons, the pool of potential non-announcers is smaller conditional on a warning being included in our final sample, resulting in fewer comparable firms for each announcement (and since a firm may be a non-announcer for more than one warning the effect is multiplicative).

${ }^{10}$ We explored results for foreign non-announcers conditional on whether the sign of their announcement-period abnormal returns is the same as that observed for announcers (contagion subsample) or opposite to that observed for announcers (competitive subsample). Splitting the sample on the basis of contagion versus competitive effects reveals statistically and economically significant signed abnormal returns of approximately $1 \%$ in magnitude in both samples. However, whereas announcement-period abnormal returns in the contagion subsample are negative, those in the competitive subsample are positive.
} 


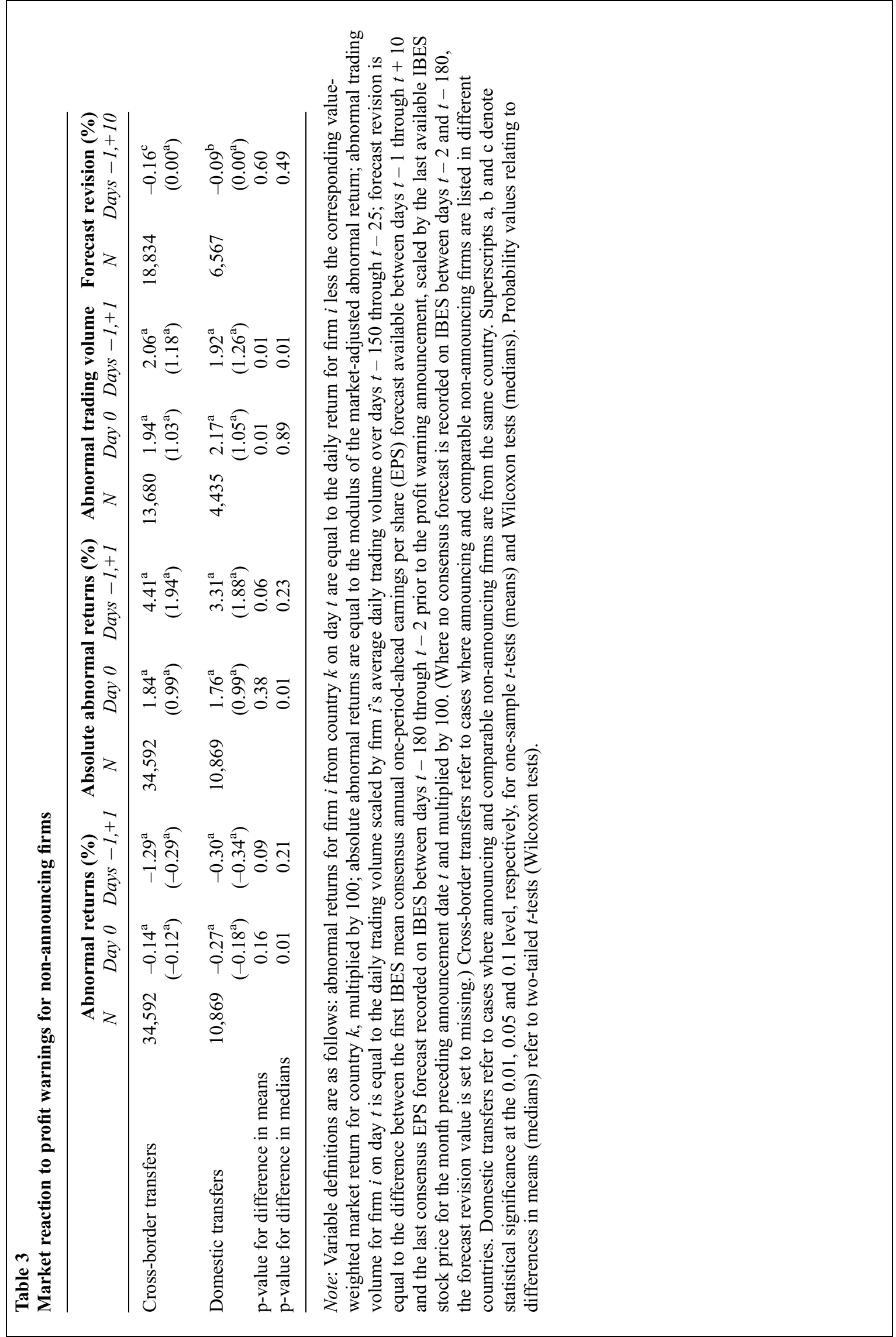


and statistically significant pricing effects: mean (median) absolute announcement-day returns are equal to $1.84 \%(0.99 \%)$, while the cumulative effect for days -1 to +1 exceeds $4.40 \%(1.90 \%)$. In absolute terms, therefore, cross-border transfers appear economically significant. The large magnitude of absolute abnormal returns (relative to signed returns) is further evidence that profit warnings lead to contagion and competitive effects for foreign non-announcers that net off when aggregated in a signed return metric.

Columns $9-10$ and 12 in Table 3 present results for abnormal trading volume and analyst forecast revisions, respectively, in response to profit warning announcements. Mean announcement-period trading volume is approximately double the normal level for comparable foreign non-announcers (significant at the 0.01 level). The mean non-announcer also experiences a statistically significant downward revision in analysts' consensus earnings forecast during the 12-day period ending 10 days after a warning is issued. Although medians are closer to zero, non-parametric tests confirm the presence of abnormally high trading volume and downward revisions in analysts' forecast. Overall, these findings are consistent with the abnormal return results and provide further evidence that profit warnings generate cross-border information transfers that on average involve contagion effects.

Comparative results for domestic non-announcers are reported beneath the cross-border findings in Table 3. Consistent with prior research, statistically significant contagion effects for domestic samesector non-announcing firms are evident. More relevant to our analysis, however, is the relative magnitude of domestic and cross-border results. Firth (1996a) predicts and finds that domestic information transfers for UK and US firms are larger than corresponding cross-border effects. Results reported in Table 3 for signed abnormal returns suggest a different pattern. Although domestic returns tend to be more negative than crossborder returns, differences are small and statistically insignificant in most cases. Only median announcement-day returns are significantly more negative for the domestic sample (at the 0.05 level). A similar pattern is evident for absolute abnormal returns and analyst forecast revisions: average cross-border effects are broadly comparable with domestic information transfers. While differences between domestic and cross-border effects are apparent for abnormal trading volume, conclusions are sensitive to choice of announcement window. The absence of systematic differences in the magnitudes of domestic and cross-border effects, and the extent to which this reflects increased levels of globalisation and cross-border trade, is a theme that we return to in Section 6.2.

\subsection{Country-level results}

Table 4 reports cross-border information transfers by country. Panel A presents evidence for foreign same-sector non-announcers conditional on the nationality of the announcing firm. (For example, where the announcing firm is French, Panel A reports the market reaction for all non-French nonannouncing peer firms.) We restrict the discussion to median values because distributions for the market reaction metrics are characterised by extreme observations. Significant cross-country variation in medians is evident for all four metrics suggesting that announcer nationality may influence the informativeness of the warning for foreign non-announcers. There is some evidence that announcers from France and countries classified as 'Others' tend to produce the largest impact on comparable foreign non-announcers whereas German and UK announcers are consistently associated with statistically significant transfers that are more moderate in magnitude. However, country rankings are unstable across the different market metrics making reliable ordering impossible. Similar results are apparent in Panel B where announcement-period effects are grouped according to non-announcing firms' nationality. (For example, we pool across all French same-sector non-announcers regardless of the nationality of announcing firms.) While significant cross-country variation is again evident across all four metrics, consistent patterns are hard to detect because country rankings vary depending on the particular market reaction variable examined.

Overall, findings presented in Table 4 suggest that both announcing and non-announcing firms' nationality may influence the form and magnitude of the information transfer. However, country effects vary considerably according to the particular market reaction metric examined and no single country or group of countries is associated with consistently strong or weak effects.

\section{Cross-sectional analysis}

To shed further light on the properties of crossborder information transfers associated with profit warnings we augment univariate market reaction results with cross-sectional tests that relate the announcement-period market response for comparable foreign non-announcers to a series of firm-, industry- and country-level attributes. The following section develops our empirical predictions and 


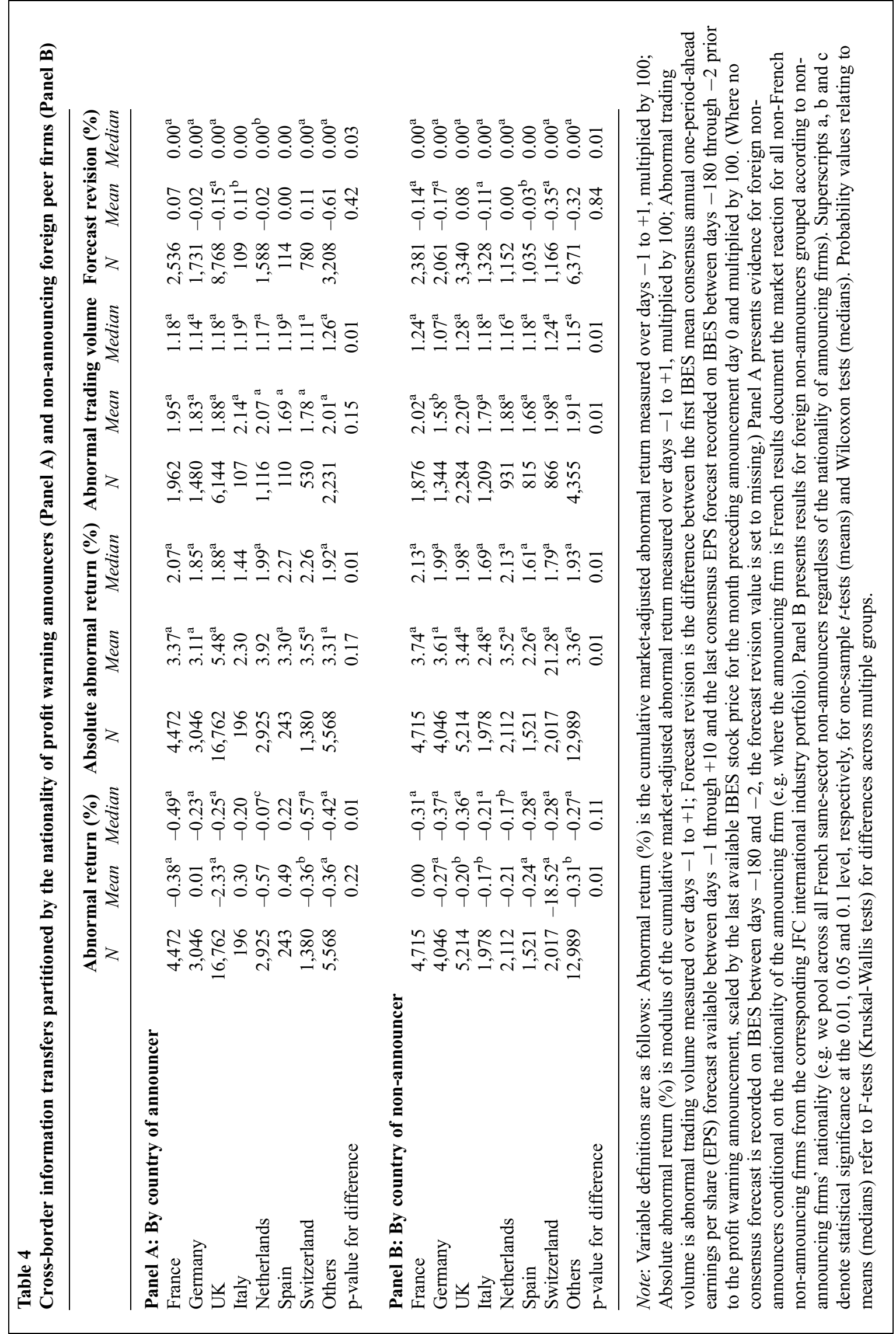


explains our modelling strategy. Results are reported in Section 5.2.

\subsection{Predictions and model}

It is well established that investors' response to earnings-related news is positively associated with the magnitude of the earnings surprise. While the majority of prior research reports evidence for announcing firms (e.g. Foster et al., 1984), findings from the information transfer literature demonstrate that domestic information spillovers are also increasing in the size of the announcing firm's earnings surprise (Foster, 1981; Thomas and Zhang, 2006). Firth (1996a) extends the analysis to crossborder transfers between US and UK firms and finds similar evidence. Consistent with Firth (1996a), therefore, we predict that cross-border information transfers in response to profit warnings are increasing in the magnitude of the negative earnings surprise observed for the announcing firm. The announcement-period abnormal return experienced by the issuing firm represents an indirect proxy for the surprise component in a warning. ${ }^{11}$ Accordingly, we predict that cross-border information transfers will be more (less) pronounced for profit warnings accompanied by large (small) negative abnormal returns.

Timely information transfers rely partly on the assumption that investors in non-announcing firm $j$ are able to identify and process relevant information released by firm $i$. Evidence of information transfers is therefore expected to be more dramatic when the barriers to identifying and processing pertinent information are low. One factor expected to help facilitate information exchange between firms is common analyst following. Analysts specialise in processing earnings-related information and understanding its implications for announcers and their competitors. For example, analysts' reports routinely discuss and evaluate earnings-related information from the perspective of an announcer's sector in general and its peers in particular. Comparative analysis of the type performed by equity analysts is expected to facilitate information exchange between peer firms. Moreover, since

\footnotetext{
${ }^{11}$ As Firth (1996a: 314) discusses, a problem with this approach is that the association between stock returns of announcing and non-announcing firms may be due to misspecification of the expected return model (e.g. marketadjusted returns fail to control for industry-related factors). The alternative approach is to use to a direct measure of earnings surprise. Unfortunately, ExtelConnect does not provide information on the magnitude of the earnings surprise associated with a profit warning. Our inability to control for the magnitude of the warning represents an important limitation of our analysis.
}

analysts specialise by sector (Ramnath et al., 2008), firms with common analysts may be considered more comparable than those characterised by wholly independent analyst coverage (Ramnath, 2002). Accordingly, the absence of at least one shared analyst may proxy for firms between which earnings information transfers are unlikely to occur. Collectively, these factors suggest that the scope for information transfers between any given firm pair will be more pronounced when both are tracked by at least one common analyst.

Cross-border information transfers are also expected to be larger when announcing and comparable non-announcing firm performance is determined by a common set of factors (Firth, 1996a). A simple measure of relatedness for any given pair of firms is the degree to which their respective stock prices covary. ${ }^{12}$ We therefore expect the magnitude of cross-border information transfers associated with profit warnings to be increasing in the degree of covariation between non-announcing firms' stock returns and those of the corresponding announcer.

The amount of common industry information contained in a profit warning is likely to vary over time with the business cycle. All else equal, warnings issued during periods of economic prosperity are more likely to reflect problems specific to an announcer rather than generic sector-wide trends. Conversely, warnings issued during periods of economic slowdown are more likely to capture systemic performance problems within a sector. As a result, the magnitude of cross-border information transfers is expected to be larger for profit warnings issued during periods of economic contraction.

Intra-industry cross-border information transfers are also expected to be contingent on the prevailing competitive structure within a sector. For example, earnings surprises are expected to provide particularly useful information for assessing the performance and value of announcers' peers in industries where firms follow similar strategies and face exposure to comparable market pressures. In contrast, earnings surprises are likely to be less informative about non-announcing firm performance and value in sectors characterised by greater product market segmentation and strategic differentiation. The level of strategic differentiation (direct competition) is expected to be decreasing (increasing) in the degree of industry concentration.

\footnotetext{
${ }^{12}$ Firth (1996a) focuses on the extent to which non-announcers' earnings covary with those of the announcing firm, based on 10 years of quarterly earnings changes. The absence of quarterly data in Europe and an insufficient time-series of annual observations for most firms prevent us from adopting a similar approach.
} 
We therefore expect cross-border information transfers in response to profit warnings to be more pronounced in concentrated industries.

Stronger cultural and economic links are predicted to reduce barriers to cross-border information flows by increasing investors' ability to obtain and interpret firm-specific information (Bell et al., 2006: 15). To the extent that social and fiscal differences inhibit the flow of information between firms in different countries, cross-border information transfers are expected to be more pronounced between firms from countries with shared economic and cultural traditions (Firth, 1996a). Our proxy for the strength of cultural and economic integration is geographic proximity: all else equal, neighbouring countries are expected to be culturally and economically more similar than geographically remote countries. We therefore predict that the magnitude of cross-border information transfers will be greater for firms from neighbouring countries relative to firms that are geographically remote.

The above predictions are tested using the following OLS regression model:

$$
\begin{aligned}
& M R_{j p t}^{m}=\gamma_{0}+\gamma_{1} A R_{i p}+\gamma_{2} \text { COMANAL }_{j t}+\gamma_{3} \text { CORR }_{j t} \\
& +\gamma_{4} \text { CLIMATE }_{t}+\gamma_{5} \text { HERF }_{j t}+\gamma_{6} \text { NEIGHBOUR }_{j} \\
& \quad+\sum_{n=1}^{N} \lambda_{n} \text { Control }_{j n}+\varepsilon_{j p t}
\end{aligned}
$$

Variable definitions for Equation (5) are as follows: $M R^{m}$ is the $m^{\text {th }}$ market reaction metric for comparable foreign non-announcer $j$ in response to profit warning $p$ released by firm $i$ at time $t$ ( $m$ equals threeday cumulative abnormal returns, absolute three-day cumulative abnormal returns, abnormal trading volume, or analysts' forecast revisions); $A R$ is the announcement-day abnormal return for announcement firm $i$ issuing profit warning $p ; C O M A N A L$ is an indicator variable that takes the value of one if nonannouncing firm $j$ has at least one analyst in common with announcing firm $i$, and zero otherwise; CORR is the Pearson correlation coefficient between stock returns for announcing firm $i$ and non-announcing firm $j$ (computed using daily returns over days $t-250$ to $t-10)$; CLIMATE is an indicator variable taking the value of one if profit warning $p$ was announced during a period of economic contraction (calendar years 2000 through 2003) and zero otherwise; HERF is the Herfindahl index of global industry concentration (computed using revenues for all firms in the corresponding JCF international industry portfolio); NEIGHBOUR is an indicator variable that takes the value of one where firms $i$ and $j$ are listed in countries that share a national border and zero otherwise;
Controls is a vector of $N$ additional factors that may also influence the magnitude of the information transfer; and $\varepsilon$ is the regression residual. Separate versions of Equation (5) are estimated for the $m$ dependent variables.

With little theory to guide the selection of appropriate control variables, our final choice is unavoidably arbitrary. We include firm size (natural logarithm of market capitalisation) because larger, higher profile firms may be associated with more pronounced information transfer effects. We also control for firms' global status (measured by inclusion in the Morgan Stanley MSCI global stock index) on the basis that cross-border information transfers may be larger for firms with greater international exposure. Analyst following is included to control for differences in firms' general information environment. We also control for GAAP regime (IFRS, US GAAP and UK GAAP versus the remainder) because cross-border information transfers could be influenced by financial reporting quality. Measures of all control variables are constructed separately for announcing and nonannouncing firms. Finally, in view of significant cross-country variation in the market reaction to profit warnings for announcers (Table 2) and nonannouncers (Table 4), we include two vectors of country indicator variables to capture unmodelled country-level effects for announcers and nonannouncers, respectively. ${ }^{13}$

As Firth (1996a: 318) discusses, coefficient predictions in regressions using signed market reaction metrics (i.e. cumulative abnormal returns and analysts' forecast errors) will differ according to whether a transfer leads to contagion or competitive effects. For example, where warnings lead to contagion, more (less) pronounced transfers should yield more (less) negative realisations of the dependent variable. In contrast, where warnings are associated with competitive effects, more (less) pronounced transfers should yield more (less) positive realisations of the dependent variable. To avoid these opposing effects netting out in the crosssection, empirical tests should allow for coefficient sign switches. We permit coefficient signs to vary according to the type of information transfer by estimating separate versions of Equation (5) conditional on contagion and competitive effects. Absent any reliable ex ante means of distinguishing between contagion and competitive transfers, we follow Firth (1996a) and use non-announcing firms'

\footnotetext{
${ }^{13}$ Sensitivity tests exploring the impact of alternative variable definitions and model specifications yield results that are similar to those reported in Table 5. Further details of these tests are presented in Section 6.2.
} 
announcement-day abnormal return realisations to partition observations. Since profit warnings represent negative earnings surprises, we interpret instances where non-announcers experience negative (positive) announcement-day abnormal returns as cases of contagion (competitive effects). Conversely, where the dependent variable in Regression (5) is an unsigned measure of market reaction (i.e. absolute abnormal returns and trading volume), coefficient signs for our test variables will remain constant irrespective of whether information transfers reflect contagion or competitive effects. Nevertheless, we follow the approach adopted for signed market response metrics and present separate results partitioned on the sign of non-announcers' returns to allow for variation in the magnitude of predicted associations between contagion and competitive effect cases.

\subsection{Results}

Table 5 reports coefficient estimates and model summary statistics for Regression (5). (Coefficient estimates are multiplied by $10^{2}$ to assist tabulation.) Panel A (B, C, and D) presents results for three-day CARs (three-day absolute CARs, three-day abnormal trading volume, and forecast revisions) partitioned according to the sign of non-announcing firms' announcement-period abnormal return. Results including and excluding control variables are reported in each case. To reduce the impact of extreme observations the 1st and 99th percentiles of the following variables are removed prior to estimation: three-day CARs, three-day abnormal trading volume, forecast revisions by model, and market value for non-announcing and announcing firms for all models. ${ }^{14}$ Since our sample contains multiple non-announcers for a single profit warning, regression residuals are likely to be correlated across firms. Further, since some firms issue multiple warnings during the sample period (see Table 1), regression residuals may also be correlated across time. Table 5 therefore reports probability values based on clustered standard errors (Petersen, 2009), with clustering performed by profit warning announcement and calendar year.

Results provide mixed evidence with respect to the predicted determinants of cross-border transfers. On the one hand, the majority of test variables display some evidence consistent with their pre-

\footnotetext{
${ }^{14}$ Results are not sensitive to alternative trimming procedures. Estimating Equation (5) prior to trimming yields broadly similar conclusions for AR, COMANAL, CORR and DECLINE. However, coefficient estimates on HERF are generally insignificant using untrimmed data. The explanatory power of all models is systematically lower pre-trimming.
}

dicted impact on cross-border information transfers. On the other hand, insofar as no variable is consistently significant with the predicted sign across all four market response metrics for both the contagion and competitive effect partitions, findings reported in Table 5 provide only partial support for the predictions developed in Section 5.1. Further, the poor explanatory power of all models presented in Table 5 suggests that the primary determinants of cross-border information transfers remain elusive.

Findings for individual test variables are as follows. Evidence supporting the prediction that cross-border transfers are increasing in the size of the earnings surprise (proxied by $A R$ ) is evident in Panels A (CARs) and B (absolute CARs) for both contagion and competitive effect samples. In contrast, estimated coefficients on $A R$ in Panel D (forecast revisions) are insignificant, although coefficient signs are as predicted, while coefficient signs in Panel C (abnormal trading volume) are contrary to predictions. Results provide no support for the prediction that cross-border information transfers are more pronounced when announcers and nonannouncers share at least one common analyst. Indeed, coefficient estimates on COMANAL are significant and in the opposite direction to our predictions in Panels A and B for Model 1, although these inconsistent findings are not apparent in Model 2 where control variables are included.

The degree of covariance between non-announcing firms' stock returns and those of the corresponding announcer is associated with cross-border transfers as predicted in Panels A (CARs) and B (absolute CARs) for models where control variables are included. Conversely, coefficient estimates on CORR in Panels $\mathrm{C}$ and D are statistically indistinguishable from zero at conventional significance levels. Evidence consistent with more pronounced cross-border transfer effects for profit warnings issued during periods of economic contraction is apparent in Panels A (CARs) and B (absolute CARs) for both contagion and competitive groups, and in Panel D (forecast revisions) for contagion cases only. Contrary to predictions, however, DECLINE is positively associated with abnormal trading volume (Panel C) and forecast revisions (Panel D) for the competitive transfer partition. Support for the predicted link between cross-border information transfers and industry concentration is also evident in Panels A and B for both contagion and competitive groups, and Panel D for the contagion group. Finally, although the magnitude of cross-border transfers varies with the strength of countries' cultural and economic links in the 
Table 5

OLS regression coefficient estimates and summary statistics for models explaining the market reaction for comparable foreign non-announcers (probability values in parentheses)

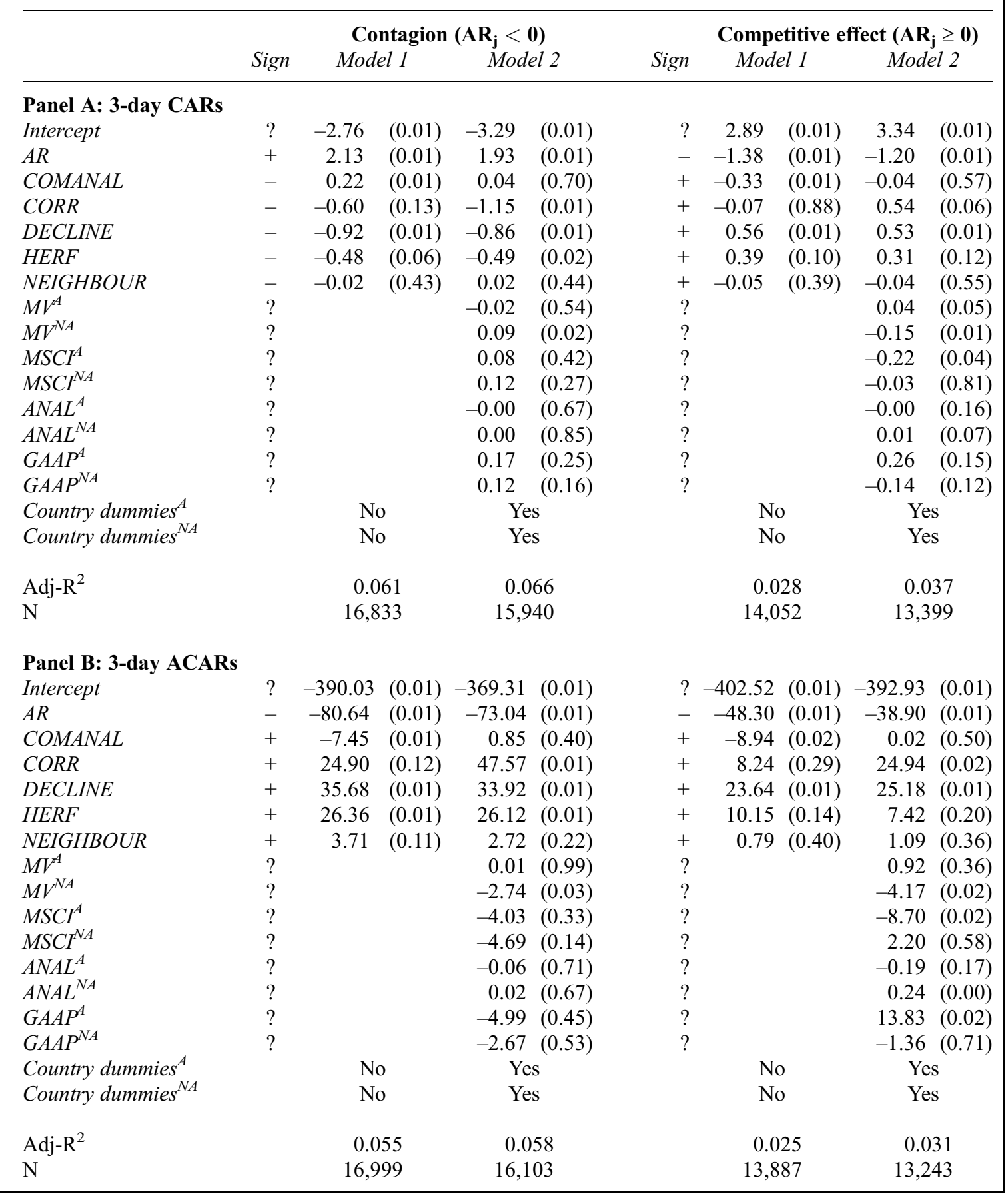


Table 5

OLS regression coefficient estimates and summary statistics for models explaining the market reaction for comparable foreign non-announcers (probability values in parentheses) (continued)

\begin{tabular}{|c|c|c|c|c|c|c|}
\hline \multirow[b]{3}{*}{ Panel C: 3-day AVOL } & \multicolumn{3}{|c|}{ Contagion $\left(\mathbf{A R}_{\mathbf{j}}<\mathbf{0}\right)$} & \multicolumn{3}{|c|}{ Competitive effect $\left(A R_{j} \geq 0\right)$} \\
\hline & \multirow[t]{2}{*}{ Sign } & Model 1 & Model 2 & \multirow[t]{2}{*}{ Sign } & Model 1 & Model 2 \\
\hline & & & & & & \\
\hline Intercept & $?$ & $-22.82(0.04)$ & $-21.72(0.27)$ & $?$ & $12.48(0.07)$ & $36.44(0.00)$ \\
\hline$A R$ & - & $17.77(0.43)$ & $14.07(0.51)$ & - & $24.63(0.04)$ & $29.69(0.02)$ \\
\hline COMANAL & + & $-2.48(0.20)$ & $0.11(0.48)$ & + & $-8.21 \quad(0.00)$ & $-5.88(0.00)$ \\
\hline CORR & + & $1.36(0.87)$ & $-1.92(0.81)$ & + & $-25.47 \quad(0.00)$ & $-14.04(0.03)$ \\
\hline DECLINE & + & $1.78(0.33)$ & $-0.66(0.90)$ & + & $-5.54(0.06)$ & $-7.74(0.07)$ \\
\hline$H E R F$ & + & $4.27(0.36)$ & $6.20(0.31)$ & + & $11.12(0.09)$ & $7.67(0.18)$ \\
\hline NEIGHBOUR & + & $0.05(0.50)$ & $-1.11(0.70)$ & + & $0.51 \quad(0.42)$ & $0.56(0.42)$ \\
\hline$M V^{A}$ & $?$ & & $0.30(0.79)$ & $?$ & & $-1.23(0.40)$ \\
\hline$M V^{N A}$ & $?$ & & $-0.59(0.57)$ & $?$ & & $-2.51 \quad(0.01)$ \\
\hline$M S C I^{A}$ & $?$ & & $3.03(0.38)$ & $?$ & & $4.51 \quad(0.30)$ \\
\hline$M S C I^{N A}$ & $?$ & & $0.64(0.84)$ & $?$ & & $-5.93(0.07)$ \\
\hline$A N A L^{A}$ & $?$ & & $-0.21 \quad(0.28)$ & $?$ & & $-0.02 \quad(0.86)$ \\
\hline$A N A L^{N A}$ & $?$ & & $-0.23(0.01)$ & $?$ & & $0.12 \quad(0.12)$ \\
\hline$G A A P^{4}$ & $?$ & & $-5.39(0.19)$ & $?$ & & $1.13(0.81)$ \\
\hline$G A A P^{N A}$ & $?$ & & $-0.12(0.98)$ & $?$ & & $-4.61 \quad(0.18)$ \\
\hline Country dummies ${ }^{A}$ & & No & Yes & & No & Yes \\
\hline Country dummies $^{N A}$ & & No & Yes & & No & Yes \\
\hline Adj-R ${ }^{2}$ & & 0.021 & 0.026 & & 0.024 & 0.030 \\
\hline $\mathrm{N}$ & & 6,639 & 6,286 & & 5,590 & 5,346 \\
\hline Panel D: FR & & & & & & \\
\hline Intercept & $?$ & $-0.03 \quad(0.59)$ & $-0.07 \quad(0.43)$ & $?$ & $-0.05 \quad(0.26)$ & $-0.13 \quad(0.01)$ \\
\hline$A R$ & + & $0.03 \quad(0.12)$ & $0.02 \quad(0.24)$ & - & $-0.01 \quad(0.80)$ & $-0.04 \quad(0.42)$ \\
\hline CONANAL & - & $-0.01 \quad(0.39)$ & $-0.01 \quad(0.34)$ & + & $0.01 \quad(0.43)$ & $(0.50)$ \\
\hline CORR & - & $-0.01 \quad(0.40)$ & $-0.01 \quad(0.33)$ & + & $-0.01 \quad(0.59)$ & -0.03 \\
\hline DECLINE & - & $-0.06 \quad(0.01)$ & $-0.06 \quad(0.01)$ & + & $-0.05 \quad(0.01)$ & -0.06 \\
\hline$H E R F$ & - & $-0.07 \quad(0.07)$ & $(0.03)$ & + & $-0.04 \quad(0.48)$ & -0.05 \\
\hline NEIGHBOUR & - & $0.02 \quad(0.05)$ & $(0.60)$ & + & $0.01 \quad(0.25)$ & $(0.20)$ \\
\hline$M V^{A}$ & $?$ & & $-0.00 \quad(0.50)$ & $?$ & & $(0.20)$ \\
\hline$M V^{N A}$ & $?$ & & $0.01 \quad(0.31)$ & $?$ & & $(0.36)$ \\
\hline$M S C I^{A}$ & $?$ & & $0.02 \quad(0.06)$ & $?$ & & -0.00 \\
\hline$M S C I^{N A}$ & $?$ & & $0.01 \quad(0.77)$ & $?$ & & -0.00 \\
\hline$A N A L^{A}$ & $?$ & & $0.00 \quad(0.14)$ & $?$ & & $(0.30)$ \\
\hline$A N A L^{N A}$ & $?$ & & $-0.00 \quad(0.01)$ & $?$ & & -0.01 \\
\hline$G A A P^{A}$ & $?$ & & $0.01 \quad(0.19)$ & $?$ & & $(0.51)$ \\
\hline$G A A P^{N A}$ & $?$ & & $0.01 \quad(0.41)$ & $?$ & & $-0.01 \quad(0.73)$ \\
\hline Country dummies ${ }^{A}$ & & No & Yes & & No & Yes \\
\hline Country dummies ${ }^{N A}$ & & No & Yes & & No & Yes \\
\hline Adj-R ${ }^{2}$ & & 0.014 & 0.016 & & 0.010 & 0.014 \\
\hline $\mathrm{N}$ & & 9,377 & 8,842 & & 7,641 & 7,268 \\
\hline
\end{tabular}

Note: The dependent variable in panels A, B, C and D is three-day cumulative abnormal returns centred on the profit warnings announcement date (CAR), absolute three-day cumulative abnormal returns (ACAR), three-day abnormal trading volume (AVOL), and revisions in analysts' consensus EPS forecast (FR), respectively. (See Tables 2-4 for dependent variable definitions.) Variable definitions for explanatory variables are as follows: $A R$ is the announcement-day market-adjusted stock return for the corresponding profit warning announcer; COMANAL is an indicator variable taking the value of one if the comparable foreigner non-announcer shares at least one analyst with the announcing firm and zero otherwise; CORR is the Pearson correlation coefficient between stock returns of the non-announcer and the corresponding announcing firm (computed using daily returns over the period $t-250$ to $t-10$ ); DECLINE is an indicator 


\begin{abstract}
Table 5
OLS regression coefficient estimates and summary statistics for models explaining the market reaction for comparable foreign non-announcers (probability values in parentheses) (continued)

variable taking the value of one if the profit warning was announced in calendar years 2000 through 2003

and zero otherwise; $H E R F$ is the Herfindahl index of global industry concentration (computed using revenues for all firms in the corresponding JCF international industry portfolio); NEIGHBOUR is an indicator variable taking the value of one where announcing and non-announcing firms are listed in countries that share a national border and zero otherwise; MV is the natural logarithm of market capitalisation; $M S C I$ is an indicator variable taking the value of one if the firm is a member of the Morgan Stanley MSCI global stock index and zero otherwise; $A N A L$ is the natural logarithm of analyst following; $G A A P$ is an indicator variable taking the value of one for firms that report using International Financial Reporting Standards, US GAAP or UK GAAP, and zero otherwise; Country dummies is a vector of indicator variables for country of listing; and subscripts $A$ and $N A$ refer to announcers and non-announcers, respectively. All variables using financial statement data are measured at the fiscal year-end immediately preceding the relevant profit warning. The full sample is partitioned according to the sign of nonannouncing firms' announcement day abnormal return $(A R)$ and separate regressions are performed for $A R<$ 0 and $A R \geq 0$. Coefficient estimates are multiplied by $10^{2}$ to assist tabulation. Probability values are based on clustered standard errors and refer to one-tailed tests where coefficient signs are as predicted and twotailed tests otherwise.
\end{abstract}

predicted direction in the majority of models presented in Table 5, coefficient estimates on NEIGHBOUR are generally insignificant.

Overall, findings for our test variables tend to be more pronounced for abnormal return metrics and weakest for abnormal trading volume. Results for several variables are not symmetric across contagion and competitive effect partitions, with stronger results typically observed for the contagion group. Comparison of Model 1 (excluding controls) and Model 2 (including controls) in each panel reveals that control variables display little incremental explanatory power beyond our main test variables. Although a number of controls display significant coefficient estimates in one or more models, consistent patterns are hard to detect. An exception is the country fixed effect vectors, the significance of which supports evidence presented in Tables 2 and 4 that cross-border information is partly contingent on country-level factors associated with both announcing and non-announcing firms, respectively.

\section{Supplementary analysis}

This section presents findings for a series of additional tests designed to further explore the form and magnitude of cross-border information transfers. In the following subsection we implement a more refined approach to distinguish between contagion and competitive transfers, while Section 6.2 summarises a battery of additional robustness tests designed to assess the sensitivity of our findings to alternative specifications and variable definitions.

\subsection{Contagion versus competitive effects}

Tests reported in the preceding section discriminate between contagion and competitive effects using the approach employed by Firth (1996a). However, partitioning solely on the basis of announcementperiod abnormal returns ignores other marketresponse indicators; and insofar as abnormal returns are measured with error, reliance on this single metric is likely to misclassify observations. We address this problem by employing an alternative partitioning method designed to provide a more refined split between contagion and competitive effects. Specifically, we use a portfolio approach whereby observations satisfying the following three conditions were classified as contagion (competitive) transfers: negative (positive) three-day CAR; threeday abnormal trading volume greater than one; and a downward (upward) revision in analysts' consensus forecast. If Firth's unidimensional approach to distinguishing between contagion and competitive transfers leads to misclassification problems and hence lower power tests, we would expect evidence of cross-border information transfers to be more pronounced using this three-way split.

The three-way classification method yields 2,486 contagion transfers and 438 competitive transfers. All remaining observations are discarded. The low number of observations classified as competitive effects is consistent with evidence that contagion transfers dominate in the cross-section. Regression (5) is re-estimated for the two groups. Coefficient estimates for our test variables and model summary statistics are presented in Table $6 .{ }^{15}$ (Results for control variables are not tabulated in the interests of parsimony.) Consistent with the view that a more

\footnotetext{
${ }^{15}$ The three-way classification is applied to the pre-trimmed sample. Variables are then trimmed separately for each regression model in Table 6 leading to minor variations in sample size across the four dependent variables.
} 


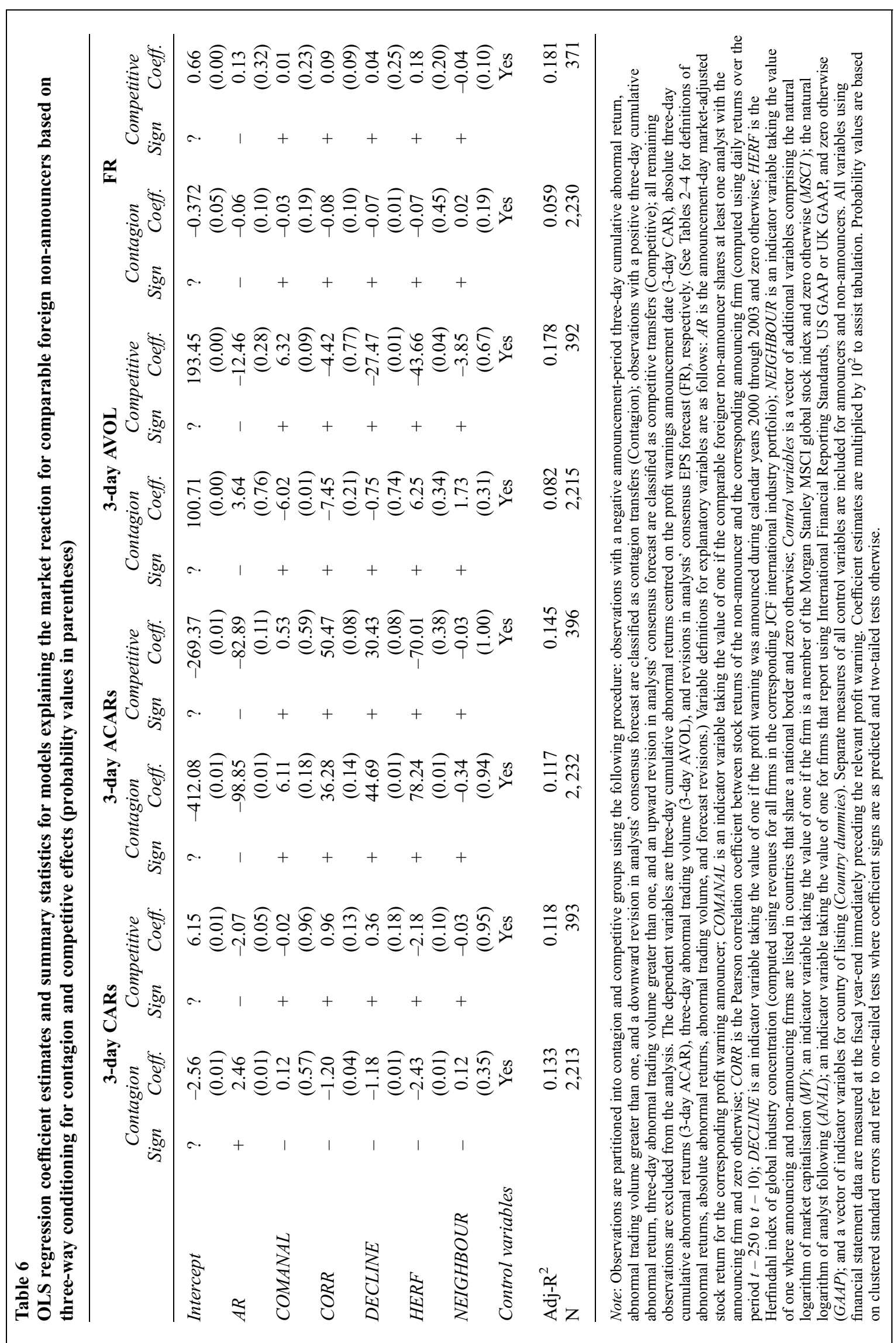


refined approach to distinguishing between contagion and competitive transfers helps reduce measurement error in the market reaction metrics, the explanatory power of all models is substantially higher than the corresponding models in Table 5. Coefficient signs and significance levels, however, are broadly similar to those previously reported with the following exceptions. In the contagion regressions, COMANAL is significant with the wrong sign in the trading volume model, CORR loses its significance in the absolute return model, and DECLINE and HERF display the wrong signs in the forecast revision model. In the competitive effect regressions, incongruous findings previously documented for AR, COMANAL and DECLINE in the trading volume model are no longer evident, CORR is significant with the predicted sign in the forecast revision model, while CORR and DECLINE are insignificant in the cumulative abnormal return model. Overall, therefore, Regression (5) continues to provide only limited insights into the determinants of cross-border information transfers. ${ }^{16}$

\subsection{Additional sensitivity tests}

The first set of robustness tests discussed in this section relates to the selection of comparable nonannouncing firms. Analyses reported in the preceding sections use industry membership to identify announcing and non-announcing peers. To the extent that industry portfolios are constructed using broad classifications that yield arbitrary firm groupings, our analyses are likely to generate noisy tests of the incidence and magnitude of cross-border information transfers. We therefore repeated key elements of our analysis using two alternative methods for selecting comparable non-announcers. First, in the spirit of Ramnath (2002) we group firms on the basis of shared analysts. For each profit warning we identify all foreign non-announcers that share at least $n$ common analysts with the announcing firm. No constraints are placed on industry membership so that announcing and non-announcing firms can be drawn from different $J F C$ international industry portfolios. Absent any clear guidance about the appropriate number of shared analysts to use, we experiment with a range of values for $n$ between 5 and 15. The approach leads

\footnotetext{
${ }^{16}$ To limit the impact of measurement error when partitioning observations solely on the basis of abnormal return, we also repeated tests after excluding cases with abnormal return estimates close to zero. Specially, we defined contagion (competitive) transfers as cases where abnormal returns $\leq$ $-0.5 \%(\geq 0.5 \%)$; all remaining observations where $-0.5 \%<$ abnormal return were excluded. Untabulated results are similar to those presented in Table 5 using the full sample.
}

to a dramatic reduction in sample size and a marked bias towards larger firms. ${ }^{17}$ Tests reveal no evidence that matching firms on the basis of shared analysts leads to more pronounced transfer effects than those reported in Tables 3 and 4 . However, there is some evidence that contagion is increasing in the number of common analysts. For example, three-day CARs (absolute CARs) decline (increase) monotonically and as the number of shared analysts rises. In contrast, three-day abnormal trading volume and analyst forecast revisions are invariant to the level of common analyst coverage.

Our second method of grouping firms uses pairwise correlations in stock returns to identify common firms. For each announcing firm we compute the pairwise return correlation with every foreign non-announcer and then define comparable foreign non-announcers as those with a correlation coefficient greater than $\rho .{ }^{18}$ Correlations are computed using daily returns for days -150 to -25 relative to the profit warning announcement. Results using values of $\rho$ between 0.3 and 0.7 yield average cross-border transfers that are either similar to or smaller than those obtained using the industry matching method. Collectively, therefore, our common analyst and correlation tests provide no evidence that measurement error in the industrybased method used to select comparable firms understates the magnitude of cross-border transfers.

Analyses presented in Sections 4 and 5 are inclusive insofar as they incorporate announcing and non-announcing firms regardless of their size or global economic significance. A weakness of this approach is that it retains small firms with less exposure to cross-border effects due to the parochial nature of their business and market. Including such firms is likely to increase noise in our tests. We therefore performed two tests where sample firms were restricted to those likely to have a more global presence. In the first set of tests, we constrained the sample to include the largest 10 firms (ranked by market capitalisation) in each country. In the second set of tests, we restricted our focus to Europeanlisted constituents of Morgan Stanley's MSCI global stock index. Cross-border information transfers associated with these two alternative sampling approaches are similar in magnitude to those reported in Tables 3 and 4, and as such provide no

\footnotetext{
${ }^{17}$ For example, restricting comparable foreign non-announcers to those that share at least five (10 or 15) analysts with the announcing firm yields a final sample of 9,338 (1,910 or 569) observations.

${ }^{18}$ The approach is extremely computer intensive. Applying this method to our sample involved computing over six million pairwise correlations.
} 
suggestion that our main findings understate the size and importance of the phenomenon.

Sample characteristics reported in Table 1 reveal that UK firms are responsible for a disproportionately large fraction $(56 \%)$ of the warnings issued during our sample period, raising the possibility that our findings may be unduly influenced by a single country. We therefore repeated our main analyses after omitting UK profit warnings. While some minor differences in results are apparent, the overall tenor of the conclusions is not affected. As an extension of this analysis, we also examined crossborder effects for a restricted set of major European economies (France, Germany, Netherlands, Spain, Italy and the UK). No material difference in results is evident using firms from these countries.

A series of supplementary tests were conducted to assess the sensitivity of results reported in Tables 4-6 to alternative event study specifications including: (i) using raw stock returns and abnormal returns estimated using the market model in place of market-adjusted returns; (ii) removing zero return observations from all test and estimation periods; and (iii) using a range of alternative announcement windows including days $(-1,0)$ and $(0,+1)$, as well as day 0 . Results display slight variation across alternative specifications, most noticeably for the regression results reported in Table 5 where some coefficient estimates change sign depending on the particular specification employed. In almost all cases, however, these sign changes are associated with insignificant coefficient estimates. Overall, the tenor of our findings and conclusions is robust to changes in key event study parameters.

Although disparities may exist between the incidence and magnitude of domestic versus cross-border information transfers, the presence of widespread inconsistencies could cast doubt on the validity of cross-border results. To the extent that evidence of material domestic information transfers provides an indication that a profit warning contains relevant information for foreign peers, we would expect the magnitude of cross-border transfers to be larger (smaller) in the presence (absence) of a material domestic transfer effect. We test this conjecture by classifying profit warnings into two samples according to whether or not the corresponding average domestic transfer (based on threeday CARs) is statistically different from zero. We then compare the average (median) cross-border market response across the two profit warning subsamples. Results for the abnormal returns metrics are consistent with our conjecture: both contagion and competitive cross-border effects are more pronounced for the subset of warnings associated with significant domestic transfers relative to those for which no significant domestic transfers exist. In contrast, no difference in the magnitude of cross-border effects conditional on the significance of domestic transfers is evident using the abnormal trading volume and forecast revision metrics.

Results presented in Table 3 reveal similarities between cross-border and domestic effects with respect to the average sign and magnitude of information transfers. In supplementary tests we examined the degree to which these average results mask changes over time in the average level of cross-border transfers relative to domestic effects. In particular, we investigated whether the relative magnitude of cross-border information transfers increased during our sample period in line with advancing globalisation. Annual comparisons of median cross-border transfers against domestic transfers reveal no evidence of a time-series shift in relative magnitudes: the average market response for comparable foreign non-announcers is similar to that observed for domestic non-announcers throughout our sample period. Accordingly, we find no evidence that cross-border effects have increased (relative to domestic transfers) in recent years despite the growth in cross-border trade and steps to harmonise international financial reporting practices.

We assessed the robustness of results reported in Table 5 to alternative definitions for a number of our test and control variables. For example, we experimented with a regional approach to measuring geographic and cultural proximity that involved allocating countries to one of five regions. A REGIONAL indicator variable was then constructed taking the value of one where announcer and nonannouncer come from countries in the same region and zero otherwise. Results provided no new insights beyond those obtained with NEIGHBOUR. We used a continuous measure of common analyst following in place of the COMANAL indicator variable. Findings based on the continuous variable were generally less pronounced than those reported for COMANAL. In other tests Spearman correlations were used in place of Pearson correlations to construct CORR and we defined DECLINE to include only warnings issued in calendar years 2000 through 2002. In neither case did these changes yield results that differed materially from those reported in Table 5. We replaced $M S C I$ with a more sophisticated measure of international exposure derived from firm-specific geographical segment data. The approach led to a considerable reduction in sample size due to 
missing geographical segments. Nevertheless, conclusions were identical to those reported in Table 5. Finally, we expanded Equation (5) to include controls for legal origin and IFRS adoption. Coefficient estimates for these variables were not significant at conventional levels and results for all other variables were unchanged.

\section{Summary and conclusions}

This paper reports evidence on the existence and magnitude of cross-border accounting information transfers associated with profit warning announcements. While prior research indicates interdependencies among firms' share prices based on key accounting disclosures and major corporate events, results are almost exclusively confined to withincountry effects. Firth (1996a) is the only study to our knowledge that examines cross-border information transfers associated with earnings disclosures. However, Firth's study is restricted to analysing transfers between firms from countries that share similar economic, institutional and financial reporting arrangements. An unresolved question is the extent to which analysts and investors extrapolate earnings information across national boundaries in the face of substantial legal, political, cultural and financial reporting differences.

We examine cross-border information transfers between European-listed firms in response to profit warnings issued between 1997 and 2007. Empirical tests are based on samples of 4,283 firms drawn from 29 European countries and 1,357 profit warnings issued by firms from 20 countries. Tests provide some evidence that negative earnings surprises affect investors' perceptions of comparable foreign non-announcing firms. However, results are far from clear-cut. Our main findings can be summarised as follows. First, there is evidence of abnormal market activity for foreign same-sector non-announcers surrounding the release of a profit warning, consistent with the existence of cross-border information transfers among European-listed firms. Second, warnings are interpreted as bad news for the average comparable foreign non-announcer, suggesting that contagion effects dominate in the cross-section. Nevertheless, markets respond positively for a surprisingly large fraction of non-announcers, reflecting either a perceived reallocation of market share within the sector or measurement error in our market reaction metrics. Third, average cross-border information transfers are similar in character to domestic transfers. To the extent that domestic accounting-related information transfers are well established in the literature, these similarities provide some comfort regarding the reliability of our cross-border evidence. Fourth, cross-sectional tests reveal that cross-border transfers vary according to firm-, industry- and country-level characteristics. However, findings vary across alternative market response metrics; associations are not symmetric with respect to contagion and competitive effects; and the explanatory power of the models is typically low.

Our analysis provides a modest step towards developing a better understanding of how investors extrapolate earnings information across national boundaries. Accordingly, many potentially interesting avenues for further research remain unexplored. First, it seems likely that our large sample analysis pools together a small number of material transfer cases with a large number of negligible responses, resulting in relatively low power tests. Further research aimed at identifying the factors that distinguish material cross-border earnings transfers from immaterial cases is likely to yield interesting insights. Second, cross-border information transfers provide a potentially interesting framework in which to explore the consequences of international accounting diversity. While investors are compelled to think globally, global investment decisions are complicated by internationally diverse accounting practices. Investors reading foreign financial statements are frequently confronted with unfamiliar reporting rules and country-specific nuances. Additionally, many countries' financial reporting rules are not necessarily designed to reflect underlying economic performance (Revsine et al., 2002; Ball et al., 2003). Our preliminary findings suggest that GAAP diversity may not represent the barrier to international information flows that some commentators and practitioners suggest. Further work exploring financial reporting comparability from an international perspective, with particular emphasis on benefits of IFRS for cross-border financial statement analysis, is likely to be of interest to academics and policymakers alike. Third, our analysis reveals considerable cross-country variation in the propensity to issue a profit warning. Research aimed at understanding how institutional factors and firm-level incentives influence the decision to warn (and to issue a management forecast more generally) is likely to prove informative, particularly to policymakers concerned with the regulation of capital markets.

\section{References}

Aharony, J. and Swary, I. (1983). 'Contagion effects of bank failures: evidence from capital markets'. Journal of Business, 56(3): 305-322.

Baginski, S. P. (1987). 'Intra-industry information transfers 
associated with management forecasts of earnings'. Journal of Accounting Research, 25(2): 196-219.

Baginski, S. P. and Kimbrough, M. D. (2002). 'The effect of legal environment on voluntary disclosure: evidence from management earnings forecasts issued in U.S. and Canadian markets'. The Accounting Review, 77(1): 25-50.

Bailey, W., Karolyi, G. A. and Salva, C. (2006). 'The economic consequences of increased disclosure: evidence from international cross-listings'. Journal of Financial Economics, 81(1): 175-213.

Bailey, W., Li , H., Mao, C. X. and Zhong, R. (2003). 'Regulation fair disclosure and earnings information: market, analyst, and corporate responses'. Journal of Finance, 58(6): 2487-2514.

Ball, R. (2006). 'International Financial Reporting Standards (IFRS): pros and cons for investors'. Accounting and Business Research, Special Issue: International Accounting Policy Forum: 5-27.

Ball, R., Kothari, S. and Wu, J. (2003). 'Incentives versus standards: properties of accounting income in four East Asian countries'. Journal of Accounting and Economics, 36(1-3): 235-270.

Bell, L., Correia de Silva, L. and Premanis, A. (2006). The Cost of Capital: An International Comparison. London: City of London.

Berglund, T. and Westerholm, P. J. (2007). 'Foreign investors' reaction to reduced profitability - does governance matter?'. Working paper, Helsinki School of Economics. Available at: http://ssrn.com/abstract=989128.

Bowen, R., Castanias, R. and Daley, L. (1983). 'Intraindustry effects of the accident at Three-Mile Island'. Journal of Financial and Quantitative Analysis, 18(1): 87111.

Cahan, S., Emanuel, D. and Sun, J. (2005). 'Shredded reputation: did Andesen's non-US clients suffer and why?'. Working paper, University of Auckland.

Clarke, A. (2001). 'The information in UK company profit warnings'. Bank of England Quarterly Bulletin, 41(1): 104-109.

Clinch, G. and Sinclair, N. (1987). 'Intra-industry information releases: a recursive systems approach'. Journal of Accounting and Economics, 9(1): 89-106.

Collett, N. (2004). 'Reactions of the London Stock Exchange to company trading statement announcements'. Journal of Business Finance and Accounting, 31(1\&2): 335.

Diaz, C. and McLeay, S. (1996). 'Bad debt provisions and intra-industry information transfer in the banking sector'. European Accounting Review, 5(4): 625-650.

Eckbo, E. (1983). 'Horizontal mergers, collusion, and stockholder wealth'. Journal of Financial Economics, 11(1-4): 241-273.

Firth, M. (1976). 'The impact of earnings announcements on the share price behaviour of similar type firms'. Economic Journal, 86(342): 296-306.

Firth, M. (1996a). 'The transmission of corporate financial information across national borders and equity market linkages'. Review of Accounting Studies, 1(4): 309-337.

Firth, M. (1996b). 'Dividend changes, abnormal returns, and intra-industry firm valuations'. Journal of Financial and Quantitative Analysis, 31(2): 189-212.

Foster, G. (1981). 'Intra-industry information transfers associated with earnings releases'. Journal of Accounting and Economics, 3(3): 201-232.

Foster, G., Olsen, C. and Shevlin, T. (1984). 'Earnings releases, anomalies and the behaviour of security returns'. Accounting Review, 59(4): 574-603.

Freeman, R. and Tse, S. (1992). 'An earnings prediction approach to examining intercompany information transfers'. Journal of Accounting and Economics, 15(4): 509 523.

Frost, C. (2000). 'Characteristics and information value of corporate disclosures of forward-looking information in global equity markets'. Working paper, University of North Texas. Available at: http://papers.ssrn.com/sol3/papers. cfm?abstract id $=10161$.

Gleason, C., Jenkins, N. and Johnson, B. (2008). 'The contagion effects of accounting restatements'. Accounting Review, 83 (1): 83-110.

Han, J. and Wild, J. (1990). 'Unexpected earnings and intraindustry information transfers: further evidence'. Journal of Accounting Research, 28(1): 211-219.

Han, J., Wild, J. and Ramesh, K. (1989). 'Managers' earnings forecasts and intra-industry information transfers'. Journal of Accounting and Economics, 11(1): 3-33.

Helbok, G. and Walker, M. (2003). 'On the willingness of UK companies to issue profit warnings: regulatory, earnings surprise permanence, and agency cost effects'. Working paper, University of Manchester.

Hertzel, M. (1991). 'The effects of stock repurchases on rival firms'. Journal of Finance, 46(2): 707-716.

Hirst, D. E., Koonce, L. and Venkataraman, S. (2008). 'Management earnings forecasts: a review and framework'. Accounting Horizons, 22(3): 315-338.

Joh, G-H. and Lee, C-W. (1992). 'Stock price response to accounting information in oligopoly'. Journal of Business, 65(3): 451-472.

Kasznik, R. and Lev, B. (1995). 'To warn or not to warn: Management disclosures in the face of an earnings surprise'. Accounting Review, 70(1): 113-134.

Lang, L. and Stulz, R. (1992). 'Contagion and competitive intra-industry effects of bankruptcy announcements'. Journal of Financial Economics, 32(1): 45-60.

Madura, J., White, A. and McDaniel, W. (1991). 'Reaction of British bank share prices to Citicorp's announced \$3 billion increase in loan loss reserves'. Journal of Banking and Finance, 15(1): 151-63.

Petersen, M. (2009). 'Estimating standard errors in finance panel data sets: comparing approaches'. Review of Financial Studies, 22(1): 435-480.

Pownall, G. and Waymire, G. (1989). 'Voluntary disclosure choice and earnings information transfer'. Journal of Accounting Research, 27 (Supplement): 85-105.

Pyo, Y. and Lustgarten, S. (1990). 'Differential intraindustry information transfer associated with managerial earnings forecasts'. Journal of Accounting and Economics, 13(4): 365-379.

Ramnath, S. (2002). 'Investor and analyst reactions to earnings announcements of related firms: an empirical analysis'. Journal of Accounting Research, 40(5): 13511376.

Ramnath, S., Rock, S. K. and Shane, P. B. (2008). 'The financial analyst forecasting literature: a taxonomy with suggestions for further research'. International Journal of Forecasting, 24(1): 34-75.

Revsine, L., Collins, D. and Johnson, B. (2002). Financial Reporting and Analysis ( $2^{\text {nd }}$ edn). New Jersey, NJ: Prentice-Hall.

Schipper, K. (1990). 'Commentary: information transfers'. Accounting Horizons, 4(4): 97-107. 
Slovin, M., Sushka, M. and Bendeck, Y. (1991). 'The intraindustry effects of going-private transactions'. Journal of Finance, 46(4): 1537-1550.

Szewczyck, S. (1992). 'The intra-industry transfer of information inferred from announcements of corporate securities offerings'. Journal of Finance, 47(5): 19351945.

Thomas, J. and Zhang, F. (2006). 'Overreaction to intraindustry information transfers?'. Working paper, Yale University.
Tse, S. and Tucker, J. (2006). 'Industry-wide dynamics in earnings warnings'. Working paper, Texas A\&M University.

Weigand, R. A. (1996). 'Trading volume and firm size: a test of the information spillover hypothesis'. Review of Financial Economics, 5(1): 47-58.

$\mathrm{Xu}, \mathrm{T}$., Najand M. and Ziegenfuss, D. (2006). 'Intra-industry effects of earnings restatements due to accounting irregularities'. Journal of Business Finance and Accounting, 33(5\&6): 696-714. 